\title{
Purified Salograviolide A isolated from Centaurea ainetensis causes growth inhibition and apoptosis in neoplastic epidermal cells
}

\author{
AKRAM GHANTOUS ${ }^{1 *}$, AHMAD ABOU TAYYOUN ${ }^{1 *}$, GHADA ABOU LTEIF ${ }^{1}$, NAJAT A. SALIBA ${ }^{2}$, \\ HALA GALI-MUHTASIB ${ }^{1}$, MARWAN EL-SABBAN ${ }^{3}$ and NADINE DARWICHE ${ }^{1}$
}

Departments of ${ }^{1}$ Biology, ${ }^{2}$ Chemistry and ${ }^{3}$ Human Morphology, American University of Beirut, Beirut, Lebanon

Received August 10, 2007; Accepted October 22, 2007

\begin{abstract}
Many of the best-selling anticancer drugs are plant-derived. We tested for the anticancer properties of extracts isolated from Centaurea ainetensis, a plant species endemic to Lebanon and which is often used in folk medicine. We performed bioassay-guided fractionation of Centaurea ainetensis extracts using a panel of normal and neoplastic murine cells to identify a component that is associated with antitumor activities. Among several compounds that were fractionated, the sesquiterpene lactone, Salograviolide A, was identified and found to exert the most significant growth inhibitory effects on neoplastic cells. At concentrations that were non-cytotoxic to primary keratinocytes, Centaurea ainetensis crude extract and Salograviolide A preferentially inhibited the proliferation of papilloma and squamous cell carcinoma (SCC) cell lines without significantly affecting the growth of normal cells. Flow cytometric analysis of DNA content indicated that the inhibition of cell proliferation by Centaurea ainetensis crude extract and Salograviolide A was due to $G_{0} / G_{1}$ cell cycle arrest and increased pre- $G_{0} / G_{1}$, respectively. The increase in pre- $\mathrm{G}_{0} / \mathrm{G}_{1}$, and presumably apoptosis induction, in Salograviolide A-treated keratinocytes was confirmed by DNA Hoechst staining. Western blot analysis and electrophoretic mobility shift assay showed that both the crude extract and the isolated molecule differentially modulated key cell cycle and apoptotic regulators as well
\end{abstract}

Correspondence to: Dr Nadine Darwiche, Biology Department, American University of Beirut, PO Box 11-0236, Beirut, Lebanon E-mail: darwichn@aub.edu.lb

${ }^{*}$ Contributed equally

Abbreviations: ROS, reactive oxygen species; $\mathrm{PMK}(\mathrm{s})$, primary mouse keratinocyte(s); SCC, squamous cell carcinoma; FBS, fetal bovine serum; K, keratin; $\mathrm{H}_{2}$ DCFDA, 2'-7'-dichlorofluorescin diacetate; Vit C, vitamin C; DTT, dithiothreitol; CDKI, cyclindependent kinase inhibitor

Key words: plant extract, Salograviolide A, skin cancer as $\mathrm{NF}-\kappa \mathrm{B}$ signaling. Salograviolide A-induced growth inhibition in neoplastic cells was mediated by the accumulation of reactive oxygen species (ROS) highlighting a potent oxidant role of this molecule. These studies suggest the potential therapeutic effects of Centaurea ainetensis, and its component, Salograviolide A, against epidermal squamous cell carcinogenesis.

\section{Introduction}

Most cancers are of epithelial origin and epidermal squamous cell carcinoma (SCC) is the most frequent $(1,2)$. A wide range of naturally occurring compounds has been identified as skin chemotherapeutic agents (3), and many, as Paclitaxel (Taxol), have been derived from plants and are among the best-selling anticancer drugs today.

Plants contain many secondary metabolites that interact in a complex manner to exert their biological activities (4). Four major groups of plant secondary metabolites have been identified: terpenes, phenolic compounds, acetogenins and alkaloids.

While screening for anti-cancer activities of Middle Eastern plant extracts, we identified the Lebanese indigenous plant, Centaurea ainetensis, to possess potent and selective activities against cancer cells.

The genus Centaurea (Asteraceae) comprises 500 species predominantly distributed around the Mediterranean area and in West Asia (5), many of which have been used for millennia in folk medicine. Several studies have revealed that the Centaurea genus is a source of many secondary metabolites that have antimicrobial, anti-inflammatory, cytotoxic and antitumor properties (6-9). Among these metabolites are sesquiterpene lactones which are the most widely investigated metabolites in these plants and which contribute significantly to their anticancer potential (7). Structure-activity relationship studies of several sesquiterpene lactones have indicated that their biological activities are mainly due to the presence of $\alpha$-, $\beta$ - unsaturated carbonyl groups $(10,11)$.

Through bioassay-guided fractionation of Centaurea ainetensis crude extract using a panel of murine skin tumor cells, we isolated a guaianolide sesquiterpene lactone, Salograviolide A, which showed a potent anti-carcinogenic potential. Both Centaurea ainetensis crude extract and 
Salograviolide A preferentially inhibited the growth of murine squamous cell lines vs. primary keratinocytes. Both treatments modulated key cell cycle and apoptotic regulators as well as NF- $\mathrm{KB}$ signaling. The anticancer properties of Centaurea ainetensis have not yet been fully investigated and our study highlights the therapeutic potential of this plant against skin cancer and a potent oxidant role of Salograviolide A.

\section{Materials and methods}

Cell culture and plant extract treatments. Primary mouse keratinocytes (PMKs) were prepared from one- to two-day-old BALB/c mice as described according to established protocols $(12,13)$ and was approved by the Institutional Animal Care and Use Committee of the American University of Beirut. The neoplastic SP-1 and 308 papilloma cell lines were produced in SENCAR and BALB/c mice, respectively, as described $(14,15)$. PAM212 is a SCC cell line that spontaneously transformed in vitro (16). The I7 is a spindle cell line derived from a skin carcinoma formed from PMKs infected with the v-ras ${ }^{H a}$ and $\mathrm{v}$-fos oncogenes and grafted to nude mice (16). All cell lines were generously provided by $\mathrm{Dr}$ Stuart H. Yuspa (NIH, Bethesda, MD).

All cells were cultured in fresh Eagle Minimum Essential Medium (Bio Whittaker, Cambrex Co., MD) containing 9\% chelated fetal bovine serum (FBS), 1\% L-glutamine and $1 \%$ penicillin-streptomysin antibiotics (Gibco-BRL Life Technologies, Carlsbad, CA). Except for the I7 cell line, the complete medium for all other keratinocytes contained no more than $0.05 \mathrm{mM} \mathrm{Ca}^{2+}$ to maintain a basal proliferating cell phenotype (17). Keratinocytes were grown in a humidified incubator which was set at $95 \%$ air and $5 \% \mathrm{CO}_{2}$ for neoplastic cell lines or $93 \%$ air and $7 \% \mathrm{CO}_{2}$ for PMKs. Cell culture medium was replenished every other day.

Methanolic extracts of Centaurea ainetensis were prepared, filter-sterilized, dissolved in distilled water and diluted in culture medium at concentrations ranging from 0.2 to $1.1 \mathrm{mg} / \mathrm{ml}$. Using bioassay-guided fractionation, Salograviolide A was purified with $0.021 \%$ yield from the Centaurea ainetensis dry plant material and was used at concentrations ranging from 4 to $16 \mu \mathrm{g} / \mathrm{ml}$ in ethanol. The concentration of ethanol in culture medium did not exceed $0.1 \%$, as such a concentration had no effect on the proliferation of all cells (data not shown).

Cytotoxicity and proliferation assays. Keratinocytes were seeded into 96-well plates at a density of 5,000 cells per well. At 50-60\% confluency, cells were treated with crude plant extract or Salograviolide A. Cytotoxicity was assayed at $6 \mathrm{~h}$ using the CytotoTox $96^{\circledR}$ non-radioactive cell cytotoxicity assay kit according to manufacturer's instructions (Promega Corp., Madison, WI). The CytoTox 96 assay quantitatively measures the activity of lactate dehydrogenase (LDH), a stable cytosolic enzyme that is released upon cell lysis. Released LDH in culture supernatants is measured with a coupled enzymatic assay which results in the conversion of a tetrazolium salt into a red formazan product, the absorbance of which is recorded at $490 \mathrm{~nm}$ using an ELISA microplate reader. Proliferation was assayed at $24 \mathrm{~h}$ using the CellTiter
$96^{\circledR}$ non-radioactive cell proliferation assay kit according to manufacturer's instructions (Promega Corp.). The proliferation assay is an MTT-based method which measures the ability of metabolically active cells to convert tetrazolium salt into a blue formazan product, the absorbance of which is recorded at $570 \mathrm{~nm}$ using an ELISA microplate reader. Cytotoxicity and proliferation results were expressed as percentage of control and were derived from the mean of quadruplicate wells.

Cell cycle analysis. Asynchronously growing keratinocytes plated in $100 \mathrm{~mm}$-tissue culture dishes were treated for 24 or $48 \mathrm{~h}$ with crude plant extract or Salograviolide A. Attached keratinocytes were trypsinized, pooled with the detached population, fixed in $80 \%$ ethanol and stained with $50 \mu \mathrm{g} / \mathrm{ml}$ propidium iodide (Sigma Chemicals Co., St. Louis, MO), as previously described (12).

Hoechst nuclear staining. Keratinocytes were grown on uncoated glass coverslips in 6-well Falcon tissue culture trays and treated with $0.1 \%$ ethanol (control) or $16 \mu \mathrm{g} / \mathrm{ml}$ of Salograviolide A. Following 24 or $48 \mathrm{~h}$, attached and detached cells were separately stained with $2 \mu \mathrm{g} / \mathrm{ml}$ Hoechst 33342 nuclear stain (Molecular Probes Inc., Eugene, OR) and fixed in $2 \%$ formaldehyde $/ 5 \%$ glycerol solution. Stained keratinocytes were then suspended in Prolong antifade (Molecular Probes Inc.), mounted on slides and analyzed separately.

Western blot analysis. Total cellular protein extracts were prepared from cultured keratinocytes, washed twice with PBS, and scraped into SDS-lysis buffer $(0.25 \mathrm{M}$ Tris- $\mathrm{HCl}, \mathrm{pH} 6.8$, $20 \%$ glycerol, $4 \%$ SDS, $0.002 \%$ bromophenol blue, $10 \%$ ßmercaptoethanol). Protein concentrations were determined using a DC protein assay kit (Bio-Rad Laboratories, Hercules, CA) according to the manufacturer's protocol. Equal amounts of total cellular proteins (up to $50 \mu \mathrm{g}$ ) were resolved by 10 $12 \%$ SDS-polyacrylamide gel electrophoresis, transferred onto polyvinylidene difluoride membranes (Amersham, Arlington, IL), and then probed with primary antibodies against keratin (K)14, Bcl 2 (N-19), p53 (FL-393), p21 [(c-19)$\mathrm{G})$ ], cyclin $\mathrm{B}_{1}(\mathrm{H}-344)$, Bax, Bcl- $\mathrm{x}_{\mathrm{L}}$, cyclin $\mathrm{D}_{1}, \mathrm{p} 16$, and $\mathrm{I}_{\kappa} \mathrm{B} \alpha$ followed by secondary antibodies conjugated with horseradish peroxidase [all antibodies, except for p53 and K14, were purchased from Santa Cruz Biotechnology (Santa Cruz, CA); p53 was obtained from Novocastra (Newcastle, UK) and K14 was kindly provided by Dr Stuart H. Yuspa]. K14 was used to ensure equal loading. The immunocomplexes were visualized using enhanced chemiluminescent kits obtained from Santa Cruz (ECL system). Bands were quantified using ImageQuant software and the Molecular Dynamics 860 System (Molecular Dynamics, Sunnyvale, CA).

Electrophoretic mobility shift assay. Nuclear protein extracts were prepared and NF- $\mathrm{BB}$ electrophoresis mobility shift assay was performed, as previously described (18). Briefly, NF-кB consensus oligonucleotides (Santa Cruz) were end-labeled with $\left[\gamma^{-}{ }^{32} \mathrm{P}\right]-\mathrm{ATP}$ using T4 polynucleotide kinase. Nuclear proteins $(10 \mu \mathrm{g})$ and labeled probe $(0.4 \mathrm{ng},>30,000 \mathrm{cpm})$ were run on a $4 \%$ non-denaturing polyacrylamide gel. The gels were dried and processed for autoradiography at $-80^{\circ} \mathrm{C}$. Specificity of NF-кB binding was assessed by competition 
experiments using 10-fold excess unlabeled or mutant NF-кB oligonucleotides.

Measurement of reactive oxygen species. Generation of intracellular ROS was measured using 2'-7'-dichlorofluorescin diacetate $\left(\mathrm{H}_{2}\right.$ DCFDA) upon oxidation to the fluorescent derivative 2'-7'-dichlorofluorescin by reactions with ROS. We used the ROS kit: $\mathrm{CM}-\mathrm{H}_{2}$ DCFDA (Molecular Probes Inc.) according to manufacturer's instructions. Keratinocytes were continuously exposed to $16 \mu \mathrm{g} / \mathrm{ml}$ of Salograviolide A for $24 \mathrm{~h}$. The anti-oxidants vitamin $\mathrm{C}$ (ascorbic acid sodium salt; Sigma Chemicals) and dithiothreitol (DTT) (FisherBiotech, Wembley, Western Australia) were added $2 \mathrm{~h}$ prior to Salograviolide A at a final concentration of $1000 \mu \mathrm{M}$. Following indicated treatments, cells were spun down and resuspended in $500 \mu \mathrm{l}$ RPMI containing $2 \%$ FBS and $10 \mu \mathrm{M}$ $\mathrm{H}_{2}$ DCFDA for $20 \mathrm{~min}$ at $37^{\circ} \mathrm{C}$. Subsequently, cells were washed twice with PBS and then analyzed with a FACS scan flow cytometer (Becton-Dickinson, San Jose, CA) with excitation set at $488 \mathrm{~nm}$ and emission at $530 \mathrm{~nm}$.

\section{Results}

Centaurea ainetensis crude extract and its isolated pure molecule, Salograviolide A, inhibit cell proliferation of murine neoplastic keratinocytes. Using an in vitro murine model of squamous cell carcinogenesis, we tested for the cytotoxicity and anti-proliferative effects of Centaurea ainetensis crude methanolic extract on cells representative of the normal and progressing stages of epidermal carcinogenesis. We used the PMKs as representatives of normal epithelial cells, the SP-1 and 308 murine papilloma cell lines as benign tumor cells, the PAM212 cell line as SCC and the spindle $\mathrm{I} 7$ cell line as representative of the highly malignant and metastatic tumor cells.

At 6 h-treatment, Centaurea ainetensis crude extract was non-cytotoxic to PMKs with concentrations ranging from 0.2 to $0.6 \mathrm{mg} / \mathrm{ml}$ but was mildly cytotoxic at $1.1 \mathrm{mg} / \mathrm{ml}$ causing a $22 \%$ cell death (data not shown). Treatment for $24 \mathrm{~h}$ at $0.6 \mathrm{mg} / \mathrm{ml}$ inhibited the growth of PAM 212 and SP-1 cell lines by $67 \pm 1 \%$ and $87 \pm 2 \%$, respectively, while decreasing the proliferation of PMKs by only $40 \pm 3 \%$ (Fig. 1A). The proliferation of 308 keratinocytes and of the aggressive I7 spindle cells decreased by $43 \pm 7 \%$ and $45 \pm 3 \%$, respectively (Fig. 1A). The inhibitory effect of the crude extract at $0.6 \mathrm{mg} / \mathrm{ml}$ on the growth of SP-1 and PAM 212 cells was only 1.7-2.2-fold stronger than that on PMKs. Therefore, using bioassay-guided fractionation, a purified bioactive molecule was isolated from the crude methanolic extract. The sesquiterpene lactone, Salograviolide A (Fig. 2), was contained in one of four subfractions and was found to exert the most significant growth inhibitory effects on neoplastic cells (data not shown).

Salograviolide A (up to $16 \mu \mathrm{g} / \mathrm{ml}$ ) was non-cytotoxic to PMKs at 6 h-treatment (data not shown). Non-cytotoxic concentrations of Salograviolide A ranging from 4 to $16 \mu \mathrm{g} / \mathrm{ml}$ were found to inhibit in a dose-dependent manner the proliferation of SP-1, PAM212 and 308 cells at $24 \mathrm{~h}$ to a larger extent than PMKs and I7 cells (Fig. 1B). Salograviolide A at $8 \mu \mathrm{g} / \mathrm{ml}$ inhibited the growth of SP-1, PAM212 and 308 cells
A

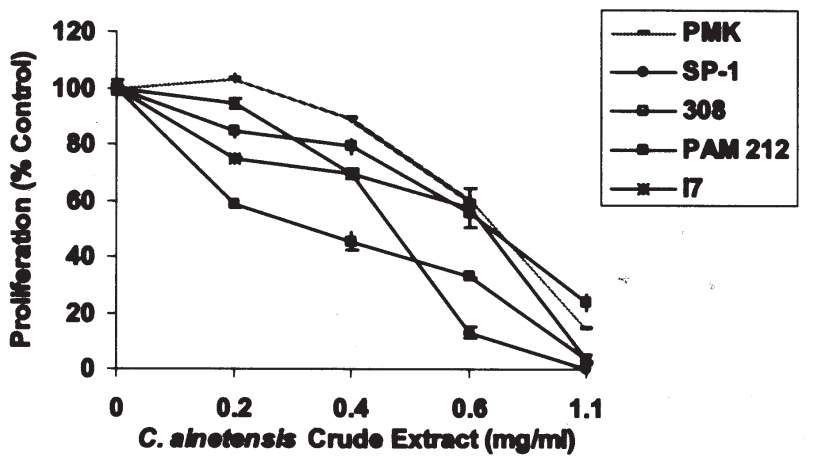

8

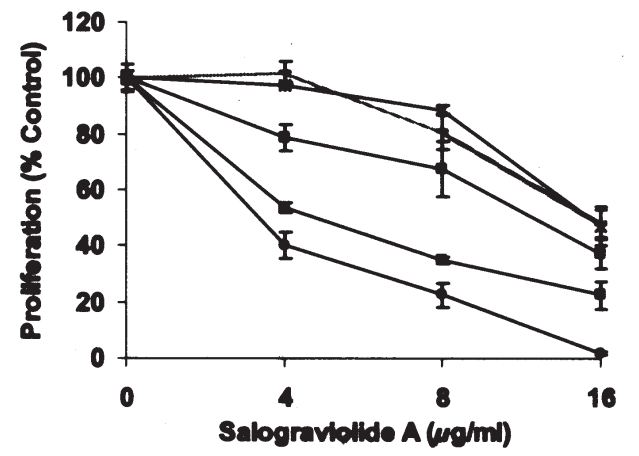

Figure 1. Effects of Centaurea ainetensis crude extract and Salograviolide A on primary and neoplastic keratinocyte cell growth. Neoplastic cells were plated in 96-well plates at a density of $1 \times 10^{5}$ cells/ml; PMKs were seeded as three mouse equivalents per plate. At 50-60\% confluency, cells were treated with different concentrations of (A) Centaurea ainetensis crude extract ( 0.2 to $1.1 \mathrm{mg} / \mathrm{ml}$ ) or (B) Salograviolide A (4 to $16 \mu \mathrm{g} / \mathrm{ml})$. Cell proliferation was determined at $24 \mathrm{~h}$ using the CellTiter 96 non-radioactive cell proliferation kit, as described in Materials and methods. Cell viability is expressed as percentage of control-treated cells for each group and are representative of at least two independent experiments. Each value represents the mean of quadruplicate measurements \pm SD

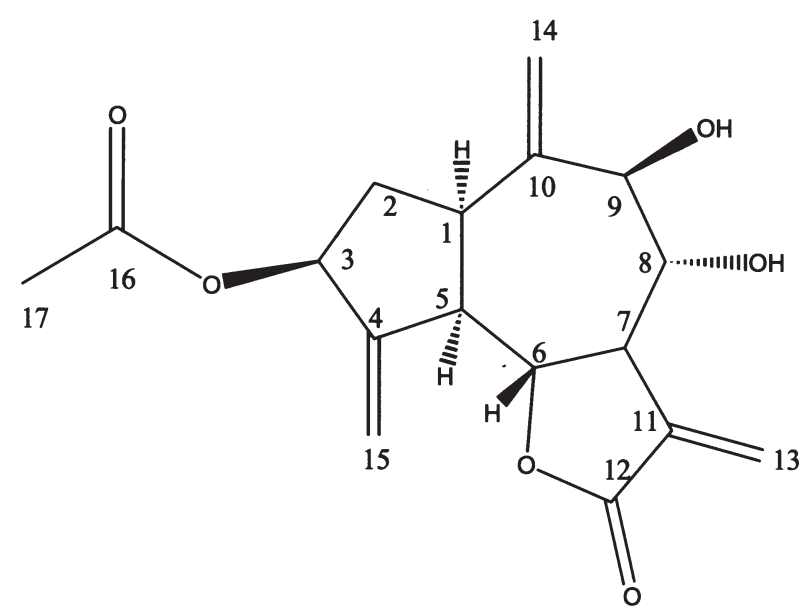

Figure 2. Chemical structure of Salograviolide A.

by $77 \pm 4 \%, 65 \pm 1 \%$ and $33 \pm 10 \%$, respectively (Fig. 1B). This concentration decreased the growth of PMKs and I7 cells by only $19 \pm 6 \%$ and $11 \pm 2 \%$, respectively. The inhibitory effect of Salograviolide A at $8 \mu \mathrm{g} / \mathrm{ml}$ on the growth of SP-1 and PAM212 cells was 3.4-4.1-fold stronger than that on PMKs. Compared to $0.6 \mathrm{mg} / \mathrm{ml}$ of the crude plant extract which 
contains only $0.1 \mu \mathrm{g} / \mathrm{ml}$ Salograviolide A, $8 \mu \mathrm{g} / \mathrm{ml}$ of Salograviolide A showed a greater selectivity towards SP-1, 308 and PAM212 cell lines vs. PMKs. The $\mathrm{IC}_{50}$ values of Salograviolide A on PMKs and I7 cells is $16 \mu \mathrm{g} / \mathrm{ml}$, while that on SP-1, PAM212 and 308 is $3.5,4.8$ and $12.7 \mu \mathrm{g} / \mathrm{ml}$, respectively.

Effects of Centaurea ainetensis crude extract and Salograviolide A on cell cycle distribution and apoptosis of neoplastic keratinocytes. Further investigations of the mechanisms of inhibition of cell proliferation were performed on SP-1 and PAM212, as these cell lines were the most sensitive to drug treatment. To determine whether the crude extract or purified molecule induce cell cycle arrest and/or apoptosis, flow cytometric analysis of propidium iodidestained DNA content and DNA Hoechst staining by fluorescence microscopy were performed. Treatment with crude extract for $24 \mathrm{~h}$ caused a dose-dependent $\mathrm{G}_{0} / \mathrm{G}_{1}$ cell cycle arrest in SP-1 (24\% increase at $0.6 \mathrm{mg} / \mathrm{ml}$; Fig. 3) and PAM212 cells ( $14 \%$ increase at $0.6 \mathrm{mg} / \mathrm{ml}$; data not shown), while no changes were observed in the pre- $\mathrm{G}_{0} / \mathrm{G}_{1}$ population for up to $48 \mathrm{~h}$ of treatment (Fig. 3; data not shown). In contrast, an increase in the pre- $\mathrm{G}_{0} / \mathrm{G}_{1}$ population of SP-1 and PAM212 cells was observed in response to incubation for $24 \mathrm{~h}$ with $16 \mu \mathrm{g} / \mathrm{ml}$ of Salograviolide A. The pre- $\mathrm{G}_{0} / \mathrm{G}_{1}$ regions of the control vs. the 24-h treated neoplastic cells increased from 3 to $20 \%$ in SP-1 cells (Fig. 3) and from 1 to $42 \%$ in PAM212 cells (data not shown). Treatment of SP-1 and PAM212 with Salograviolide A for $48 \mathrm{~h}$ further increased the pre- $\mathrm{G}_{0} / \mathrm{G}_{1}$ regions to 62 and $46 \%$, respectively (data not shown). Up to 48 -h treatment of SP-1 or PAM212 cell lines, Salograviolide A did not induce $G_{0} / G_{1}, S$ or $G_{2} / M$ cell cycle arrest (Fig. 3; data not shown).

To confirm whether the increase in pre- $G_{0} / G_{1}$ regions in the Salograviolide A-treated keratinocytes was due to apoptosis induction, cells were stained with Hoechst. Incubation with $16 \mu \mathrm{g} / \mathrm{ml}$ Salograviolide A for $24 \mathrm{~h}$ induced slight chromatin condensation in attached SP-1 cells (data not shown) and did not induce sufficient cell detachment to observe chromatin condensation in shed cells. However, following $48 \mathrm{~h}$-treatment with $16 \mu \mathrm{g} / \mathrm{ml}$ of Salograviolide A, the attached SP-1 cells exhibited partial chromatin condensation (Fig. 4, arrows) and the detached keratinocytes showed complete chromatin condensation (Fig. 4, arrowheads). This is supported by our previous results which showed that $16 \mu \mathrm{g} / \mathrm{ml}$ of Salograviolide A caused in SP-1 cells an increase in the pre $-\mathrm{G}_{0} / \mathrm{G}_{1}$ regions up to $20 \%$ after 24 h-treatment vs. $62 \% 48$ h-post treatment.

Centaurea ainetensis crude extract and Salograviolide A modulate key cell cycle and apoptotic regulators. To investigate the effects of crude extract $(0.4 \mathrm{mg} / \mathrm{ml})$ and purified molecule $(4,8$ and $16 \mu \mathrm{g} / \mathrm{ml})$ on key mediators of cell cycle and apoptosis, we examined changes in the protein expression levels of cyclin-dependent kinase inhibitors (CDKIs p16, p21), cyclins ( $\mathrm{D}_{1}$ and $\mathrm{B}_{1}$ ), the tumor suppressor protein $\mathrm{p} 53$ and $\mathrm{Bcl}_{2}$ family members $\left(\mathrm{Bax}, \mathrm{Bcl}_{2}\right.$ and $\left.\mathrm{Bcl}-\mathrm{x}_{\mathrm{L}}\right)$.

After treatment of SP-1 cells with crude extract or Salograviolide $A$, cyclin $\mathrm{D}_{1}$ protein levels were decreased or

\begin{tabular}{|c|c|c|c|}
\hline & \multirow{2}{*}{$\begin{array}{l}\text { Treatment } \\
\text { Conditions } \\
\end{array}$} & \multicolumn{2}{|c|}{$\%$ Total Cell Number } \\
\hline & & Pre- $G_{0} / G_{1}$ & $G_{0} / G_{1}$ \\
\hline \multirow{4}{*}{$\begin{array}{l}\text { C. ainetensis Crude Extract } \\
(\mathrm{mg} / \mathrm{ml})\end{array}$} & Control & 3 & 59 \\
\hline & 0.2 & 3 & 62 \\
\hline & 0.4 & 3 & 69 \\
\hline & 0.6 & 1 & 73 \\
\hline \multirow{4}{*}{$\begin{array}{c}\text { Salograviolide A } \\
(\mu \mathrm{g} / \mathrm{ml})\end{array}$} & Control & 3 & 54 \\
\hline & 4 & 1 & 64 \\
\hline & 8 & 4 & 56 \\
\hline & 16 & 20 & 54 \\
\hline
\end{tabular}

Figure 3. Effects of Centaurea ainetensis crude extract and Salograviolide A on the cell cycle distribution of SP-1 papilloma cells. SP-1 cells were plated in $100 \mathrm{~mm}$-culture dishes at a density of 50,000 cells $/ \mathrm{ml}$. At $50-60 \%$ confluency, keratinocytes were treated for $24 \mathrm{~h}$ with corresponding vehicle control or with different concentrations of Centaurea ainetensis crude extract $(0.2$ to $0.6 \mathrm{mg} / \mathrm{ml})$ or Salograviolide A (4 to $16 \mu \mathrm{g} / \mathrm{ml})$. Attached and detached cells were pooled and stained with propidium iodide. DNA content was quantified by flow cytometry. The distribution of cells in the pre- $G_{0} / G_{1}$ and the different phases of the cell cycle was determined using the CellQuest histogram analysis program. Results are representative of two independent experiments.

rendered undetectable; whereas, cyclin $\mathrm{B}_{1}$ and $\mathrm{p} 53$ proteins levels were unchanged (Fig. 5). Similar results were obtained in crude extract-treated PAM212 cells (data not shown). In contrast, p16 protein levels were increased as early as $2 \mathrm{~h}$ following both treatment conditions and were then decreased or rendered undetectable at later time points (Fig. 5). Similarly, p21 protein levels increased in crude extract or purified molecule treated-keratinocytes (Fig. 5).

Then, changes in the pro-apoptotic Bax and anti-apoptotic $\mathrm{Bcl}_{2}$ proteins were monitored upon treatment with the crude plant extract or with Salograviolide A. An increase in the ratio of pro-apoptotic over anti-apoptotic proteins leads to an increase in mitochondrial permeability and subsequent release of cytochrome c, an event central to apoptosis signaling (19). Bax protein levels are undetectable in control SP-1 cells. Treatment of SP-1 cells with crude extract resulted in time-dependent increases in Bax protein levels starting $8 \mathrm{~h}$ post-treatment (Fig. 5A), and a gradual decrease in $\mathrm{Bcl}_{2}$ protein levels as early as $2 \mathrm{~h}$ to reach undetectable levels by $12 \mathrm{~h}$. However, Salograviolide A induced an early and sharp increase in Bax proteins with undetectable changes in the protein levels of $\mathrm{Bcl}_{2}$ or of its anti-apoptotic relative, $\mathrm{Bcl}-\mathrm{x}_{\mathrm{L}}$ (Fig. 5B; data not shown). Treatment of SP-1 cells with the other concentrations of Salograviolide A (4 and $8 \mu \mathrm{g} / \mathrm{ml}$ ) resulted in similar trends of the aforementioned cell cycle and apoptotic regulator proteins as $16 \mu \mathrm{g} / \mathrm{ml}$ (Fig. 5B; data not shown).

Centaurea ainetensis crude extract and Salograviolide A regulate $N F-\kappa B$ signaling. $\mathrm{NF}-\kappa \mathrm{B}$ is a ubiquitous transcription factor that mediates growth and apoptotic effects of 


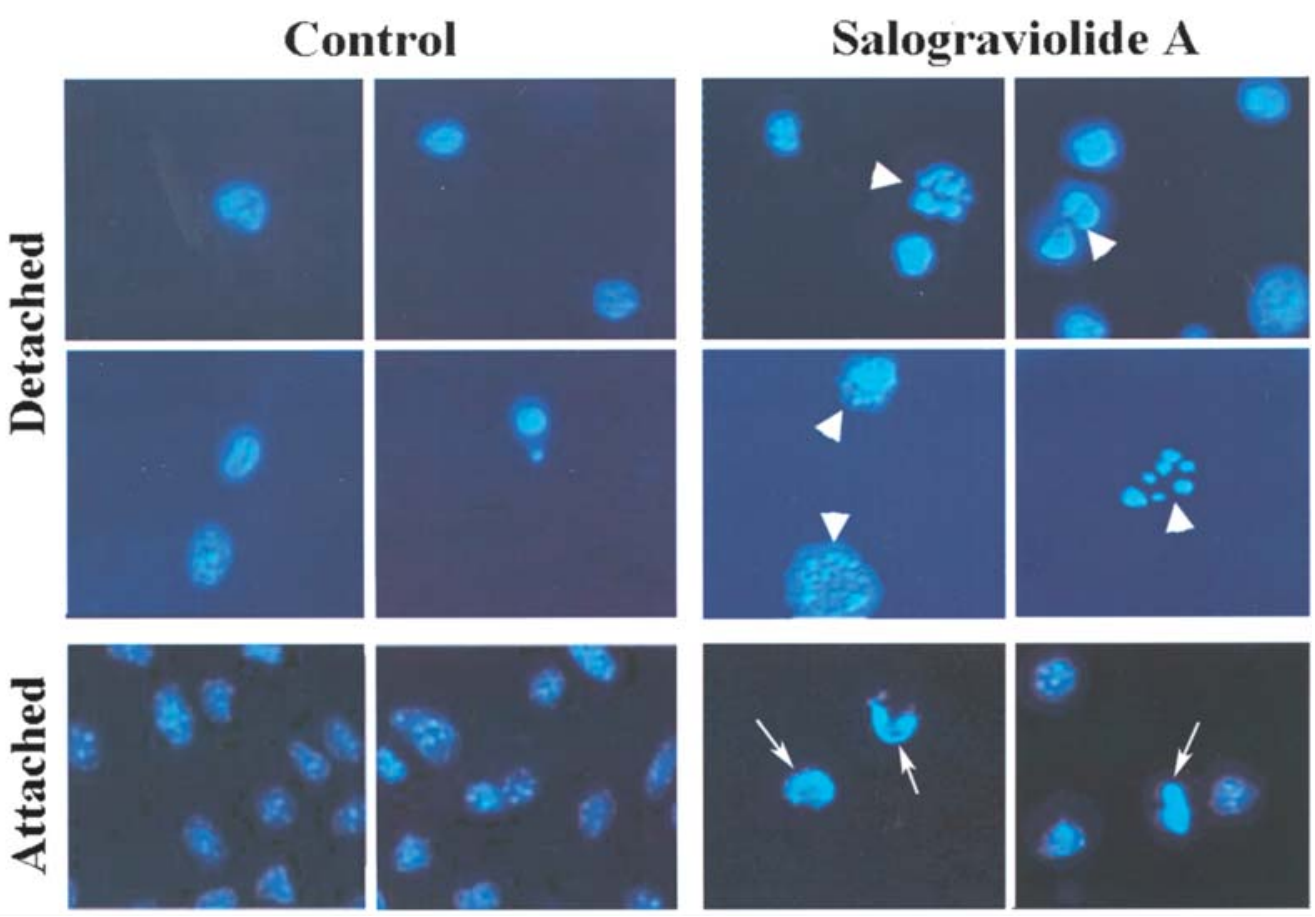

Figure 4. Salograviolide A induces apoptosis in SP-1 papilloma cells. SP-1 cells were grown on uncoated glass coverslips and treated, when 50-60\% confluent, either with ethanol $(0.1 \%)$ or with $16 \mu \mathrm{g} / \mathrm{ml}$ of Salograviolide A. After $48 \mathrm{~h}$-treatment, detached and attached cells were stained with Hoechst and mounted separately in antifade, as described in Materials and methods. Hoechst staining reveals chromatin condensation characteristic of apoptosis. Arrowheads indicate apoptotic cells which display a pattern of condensed and fragmented nuclei; whereas, arrows indicate partial chromatin condensation. Results are representative of two independent experiments.
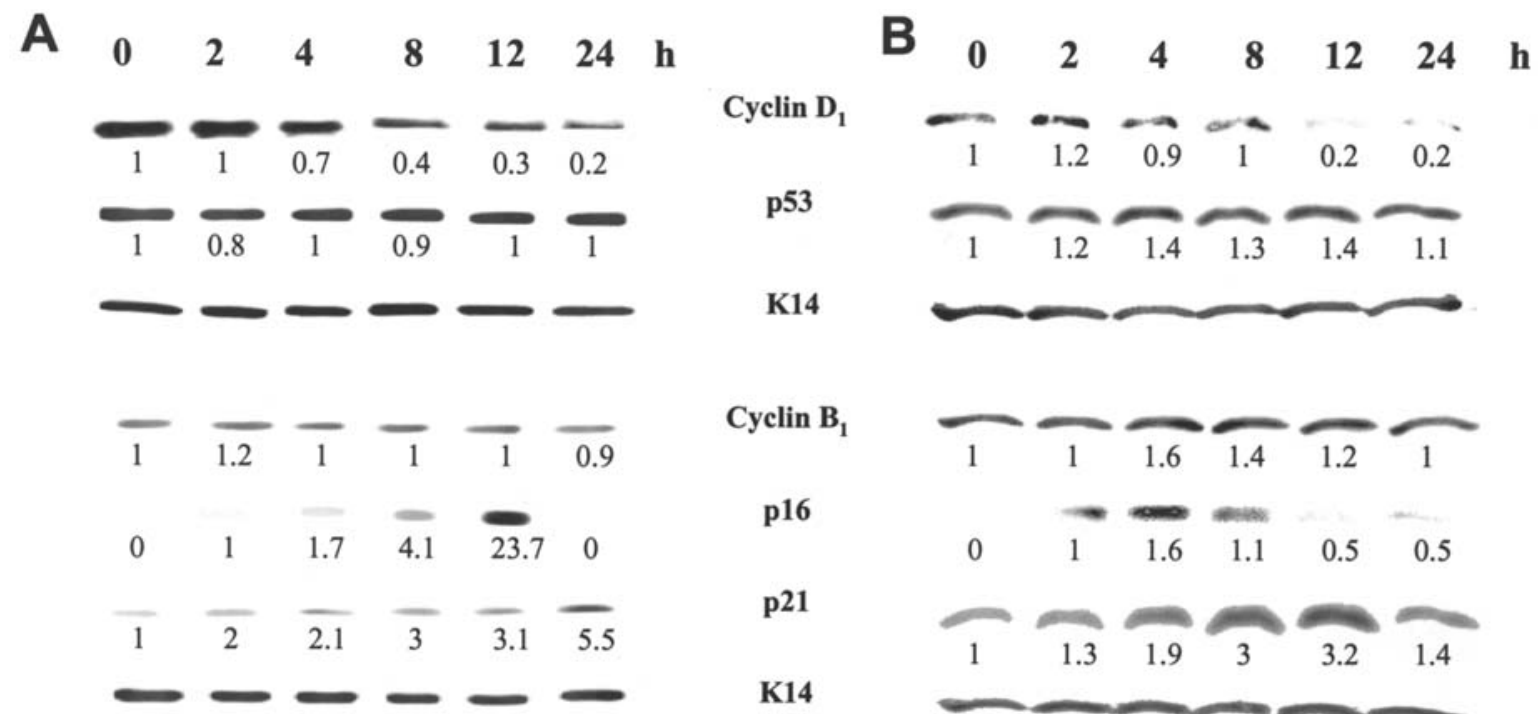

Cyclin $D_{1}$
p53
K14
Cyclin B
p16
p21
K14
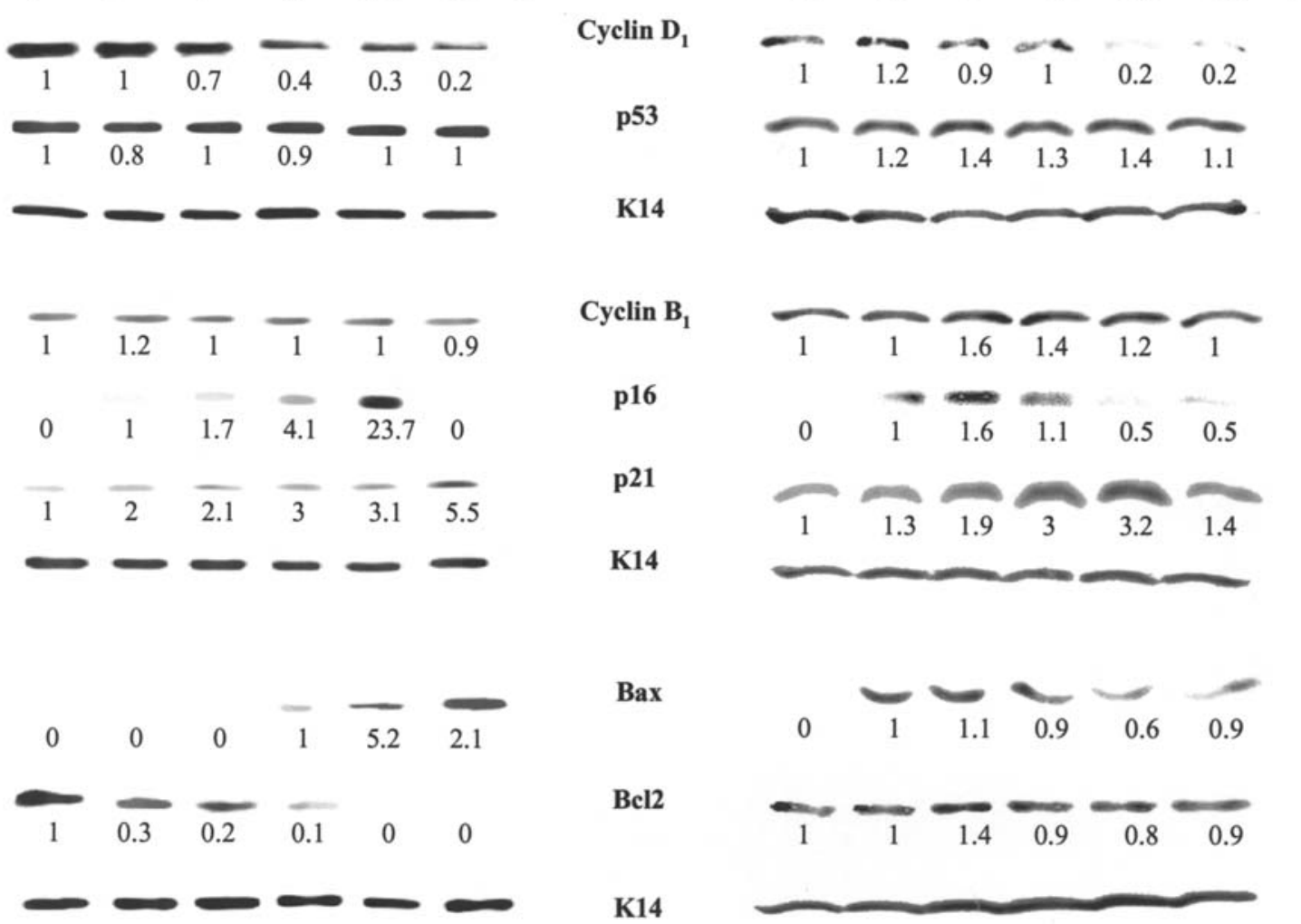
Bax
Bel2
K14
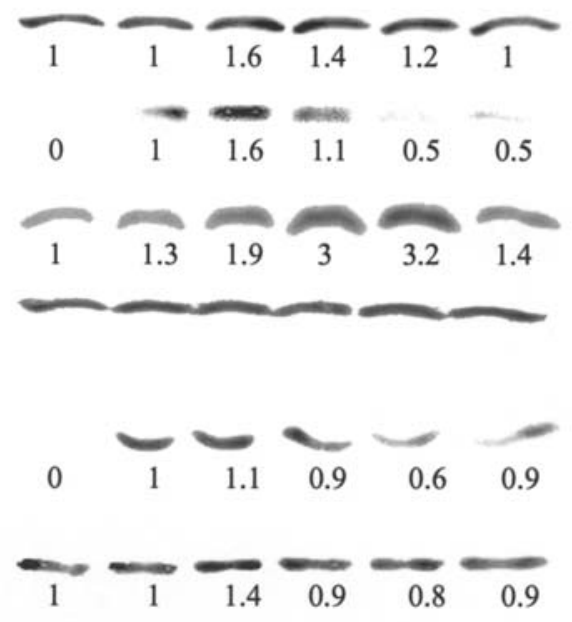

Figure 5. Centaurea ainetensis crude extract and Salograviolide A differentially modulate cell cycle and apoptotic regulators in SP-1 papilloma cells. SP-1 cells were plated in $100 \mathrm{~mm}$-culture dishes at a density of 50,000 cells $/ \mathrm{ml}$. At 50-60\% confluency, cells were treated with $0.4 \mathrm{mg} / \mathrm{ml}$ of Centaurea ainetensis crude extract (A) or Salograviolide A $(16 \mu \mathrm{g} / \mathrm{ml})$ (B) for the indicated time points. Whole cell protein lysates were prepared and immunoblotted with either cyclin $\mathrm{D}_{1}$, p53, cyclin $\mathrm{B}_{1}, \mathrm{p} 16, \mathrm{p} 21, \mathrm{Bax}$, or $\mathrm{Bcl}_{2}$. Blots were stripped and reprobed with $\mathrm{K} 14$ to ensure equal protein loading. Bands were quantified and expressed as fold of control cells, set as one, or as indicated. Results are representative of at least two independent experiments. 


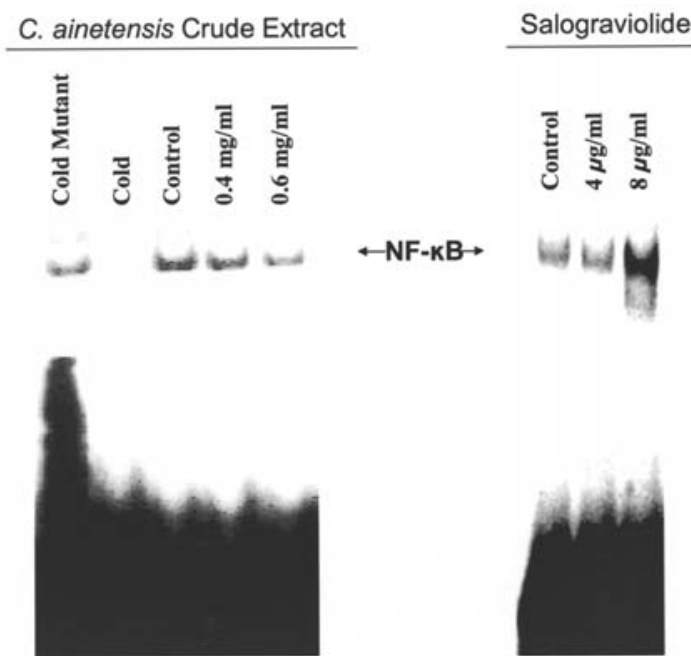

Figure 6. Centaurea ainetensis crude extract and Salograviolide A differentially regulate NF- $\mathrm{kB}$ DNA-binding activities in SP-1 papilloma cells. SP-1 cells were plated in $100 \mathrm{~mm}$-culture dishes at a density of 50,000 cells $/ \mathrm{ml}$. At 50-60\% confluency, cells were treated for $24 \mathrm{~h}$ either with corresponding vehicle control or with the indicated concentrations of Centaurea ainetensis crude extract or Salograviolide A. Electrophoretic mobility shift assay was determined, as described in Materials and methods. Competition of binding was observed upon the addition of 10 -fold excess cold probe, but not with the addition of 10 -fold excess cold mutant probe. Results are representative of two independent experiments. both external and internal stimuli and is a prime target of several plants with antitumor activities (20). Therefore, we investigated whether Centaurea ainetensis crude extract and Salograviolide A modulate $\mathrm{NF}-\kappa \mathrm{B}$ activity.

$\mathrm{NF}-\kappa \mathrm{B}$ activity is tightly regulated by many inhibitors including I $\mathrm{K} \mathrm{B} \alpha$. Several signaling cascades lead to the phosphorylation of this inhibitor, its subsequent degradation, and the translocation of $\mathrm{NF}-\kappa \mathrm{B}$ into the nucleus where it binds its consensus sequence and activates many genes. Hence, we monitored $\mathrm{I} \kappa \mathrm{B} \alpha$ protein levels at several time points after treatment. SP-1 cells treated with either the crude extract or Salograviolide A did not show any changes in $\mathrm{I} \kappa \mathrm{B} \alpha$ protein levels (data not shown). However, the activity of NF- $\kappa \mathrm{B}$ is not solely mediated by ІкB $\alpha$. Therefore, we performed a gel shift mobility assay using an NF- $\mathrm{B}$ consensus oligonucleotide to test for NF- $\mathrm{KB}$ DNA-binding activity. A dose-dependent decrease in $\mathrm{NF}-\kappa \mathrm{B}$ binding activity was observed upon treatment of SP-1 and PAM212 with 0.4 or $0.6 \mathrm{mg} / \mathrm{ml}$ of the crude plant extract for $24 \mathrm{~h}$ (Fig. 6; data not shown). When Salograviolide A was administered to SP-1 cells, NF- $\kappa B$ DNA-binding activity was unaltered at $4 \mu \mathrm{g} / \mathrm{ml}$ but potently increased at $8 \mu \mathrm{g} / \mathrm{ml}$ (Fig. 6). The NF-кB DNA binding to its labeled consensus sequence is specific since it disappeared upon the addition of excess cold probe and was sustained

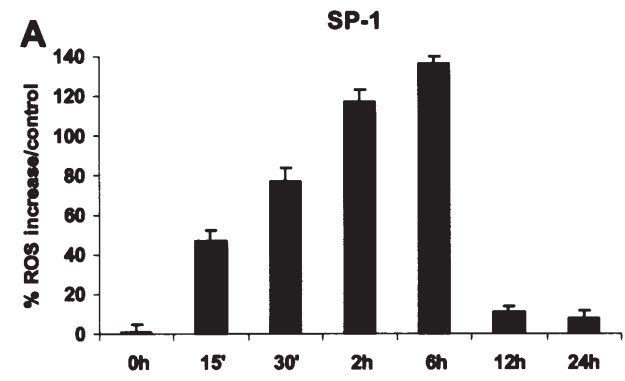

B

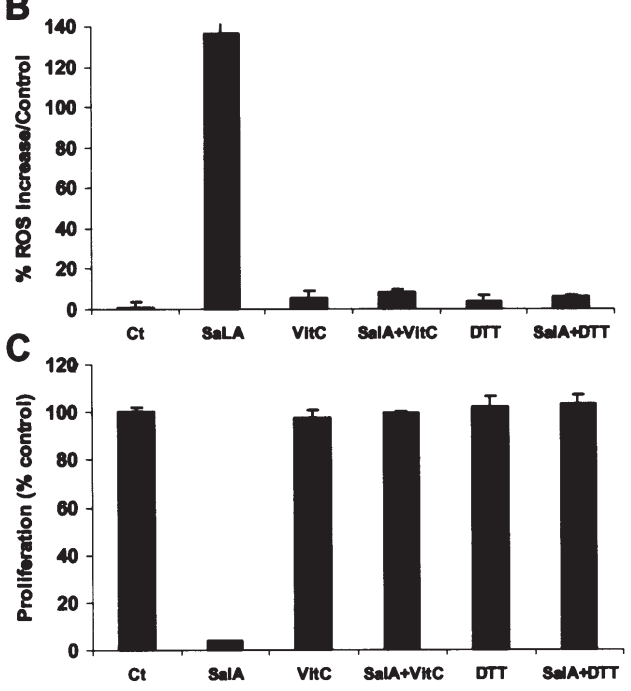

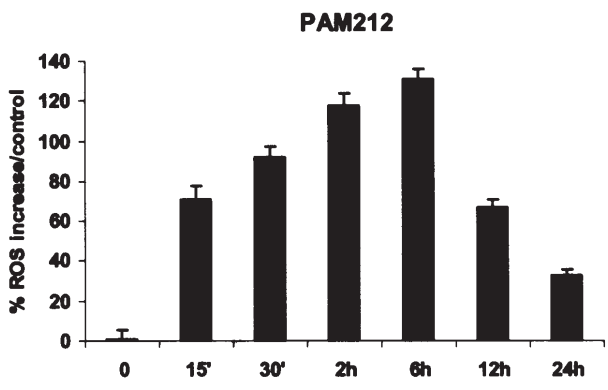
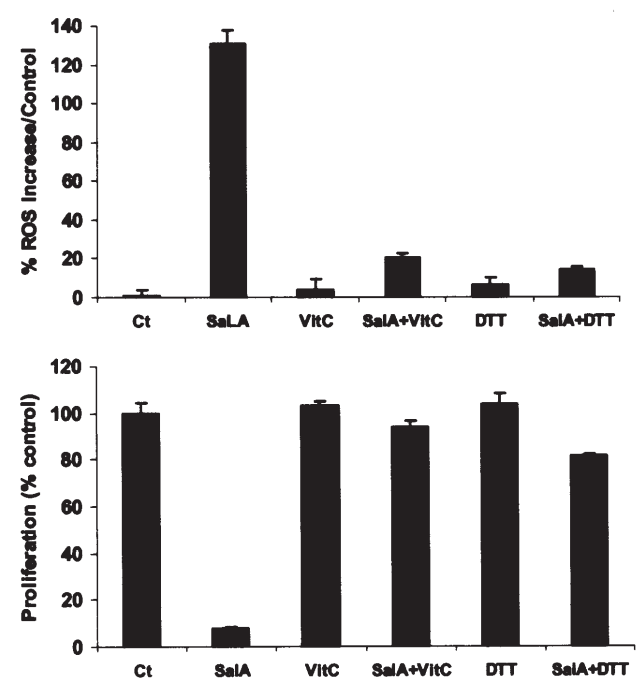

Figure 7. Reactive oxygen species accumulation mediates Salograviolide A-induced growth inhibition in neoplastic keratinocytes. SP-1 and PAM212 cells were continuously exposed to $16 \mu \mathrm{g} / \mathrm{ml}$ of Salograviolide A and ROS levels were determined by the $\mathrm{H}_{2}$ DCFDA assay for the indicated time points. (A) ROS levels, calculated from duplicate measurements, are expressed as percentage increase over control, set as one, and represent the mean \pm range ( $\mathrm{n}=2$ ). SP-1 and PAM 212 cells were treated either with $0.1 \%$ ethanol (as control), $16 \mu \mathrm{g} / \mathrm{ml}$ of Salograviolide A (SalA), $1000 \mu \mathrm{M}$ vitamin C (VitC) or $1000 \mu \mathrm{M}$ DTT or for $2 \mathrm{~h}$ with vitamin C or DTT prior to Salograviolide A treatment. (B) ROS levels and (C) cell growth were then calculated at 6 and 24 h of treatment, respectively. ROS levels were calculated from duplicate measurements and are expressed as percentage increase over control (Ct) set as one. Each bar represents the mean \pm range $(n=2)$. Cell proliferation was assayed in quadruplicate wells with the CellTiter 96 non-radioactive cell proliferation kit. Cell proliferation is expressed as percentage of control $(\mathrm{Ct})$ and represents the mean of quadruplicate measurements $\pm \mathrm{SD}$. Results are representative of two independent experiments. 
upon the addition of excess mutant cold probe which lacks affinity to the $\mathrm{NF}-\kappa \mathrm{B}$ transcription factor.

Reactive oxygen species accumulation mediates Salograviolide A-induced growth inhibition. Several recent studies have shown that sesquiterpene lactones sensitize human cancer cells to chemotherapeutic drugs as a result of ROS generation and regulation of the $\mathrm{NF}-\mathrm{\kappa B}$ signaling pathway. Moreover, oxidative stress was shown to induce apoptosis in cancer through NF- $\kappa \mathrm{B}$ activation (21).

To investigate the involvement of ROS in Salograviolide A-mediated growth inhibition, we measured ROS levels at different time points following treatment of SP-1 and PAM212 cells with the most potent tested concentration of Salograviolide A $(16 \mu \mathrm{g} / \mathrm{ml})$. Salograviolide A-induced growth inhibition was preceded by an early and progressive accumulation of ROS in both cell lines (Fig. 7). ROS levels increased in Salograviolide A-treated SP-1 and PAM212 cell lines, as early as $15 \mathrm{~min}$, by 47 and $71 \%$ of control cells, respectively (Fig. 7A). These oxidant levels peaked at $6 \mathrm{~h}$ reaching 136 and $131 \%$ of control in SP-1- and PAM212treated cells, respectively. Altogether, these results indicate that Salograviolide A-induced growth inhibition is associated with early ROS accumulation in SP-1 and PAM212 cells.

To explore the direct role of the observed ROS accumulation in Salograviolide A-induced growth inhibition, SP-1 and PAM212 cells were pre-treated for $2 \mathrm{~h}$ with the antioxidant agents, vitamin $\mathrm{C}$ and DTT and then exposed to $16 \mu \mathrm{g} / \mathrm{ml}$ Salograviolide A for $24 \mathrm{~h}$. Both vitamin C and DTT completely abrogated Salograviolide A-induced ROS generation in both cell lines (Fig. 7B). This was accompanied by a reversal of Salograviolide A-induced growth inhibition in treated cells (Fig. 7C). These results indicate that ROS accumulation directly mediate Salograviolide A-induced growth inhibition in neoplastic epidermal cells, suggesting that this molecule is a potent oxidant.

\section{Discussion}

We tested and characterized the antitumor properties of Centaurea ainetensis crude extract and its purified molecule, Salograviolide A, using an in vitro murine model of epidermal squamous cell carcinogenesis. Taking into account that a plant could contain many metabolites acting at many target sites in a given physiological process (4), the assessment of the tumor stage-specific or multi-target effects of a plant extract becomes most suitably applicable to the skin model of carcinogenesis (22).

Treatment of various murine cell lines and primary keratinocytes with Centaurea ainetensis crude extract or the isolated guaianolide, Salograviolide A, preferentially inhibited the proliferation of neoplastic epidermal cells. The most aggressive I7 spindle cells were relatively resistant. The crude plant extract and Salograviolide A display little or no cytotoxicity at the tested concentrations against primary keratinocytes.

Whereas the crude plant extract induced $G_{0} / G_{1}$ cell cycle arrest without apoptosis induction, Salograviolide A induced apoptosis in SP-1 and PAM212 cells. All the murine neoplastic cell lines employed in our study contain a characteristic oncogenic mutation of the $\operatorname{ras}^{\mathrm{Ha}}$ gene and overexpress cyclin $\mathrm{D}_{1}$. It is well established that cyclin $\mathrm{D}_{1}$ is a critical target for oncogenic ras in mouse skin and that the $\operatorname{ras}^{\mathrm{Ha}}$ oncogene signals through cyclin $\mathrm{D}_{1}$ to promote tumorigenesis (23). Both crude extract and Salograviolide A caused a down-regulation of cyclin $\mathrm{D}_{1}$ protein levels in neoplastic keratinocytes.

This observed cyclin $\mathrm{D}_{1}$ down-regulation was concomitant with an earlier up-regulation of the CDKIs p16 and p21. There is compelling evidence that the induction of $\mathrm{p} 16$ proteins increases the sensitivity of tumors to chemotherapeutic drugs (24). There is also evidence that $\mathrm{p} 21$ promotes $\mathrm{Ca}^{2+}$-induced keratinocyte differentiation. However, sustained expression of p21 renders normal keratinocytes unable to complete their differentiation program in response to high $\mathrm{Ca}^{2+}$ levels. Therefore, the rapid subsequent destruction of $\mathrm{p} 21$ proteins is necessary for the progression of differentiation (25), a process intimately connected with cell death and shedding of epidermal cells (22). Indeed, Salograviolide A-treated papilloma cell lines transiently up-regulate p21 protein levels in a curvilinear manner consistent with apoptosis induction and keratinocyte shedding. However, crude extract-treated SP-1 cells up-regulate p21 proteins without causing their subsequent degradation consistent with the associated $\mathrm{G}_{0} / \mathrm{G}_{1}$ cell cycle arrest.

$\mathrm{NF}-\kappa \mathrm{B}$ is a transcription factor pleiotropically involved in apoptosis and cell cycle control. Treatment of neoplastic keratinocytes with Centaurea ainetensis crude extract caused a dose-dependent decrease in both of NF- $\mathrm{KB}$ DNA binding activity and cyclin D1 protein levels. Several anticancer dietary agents have been found to be potent inhibitors of NF- $\mathrm{B}$ (26). Furthermore, it was shown that inactivating $\mathrm{NF}-\kappa \mathrm{B}$ in PAM-LY-2 cells, an aggressive murine SCC cell line, inhibits its malignant phenotype (27). In contrast, Salograviolide A-treated neoplastic keratinocytes increases NF- $\kappa$ B DNA binding activity.

There are conflicting results as to the role of $N F-\kappa B$ signaling in skin cancer. Studies of human and murine models of epidermal squamous cell carcinogenesis show frequent NF- $\mathrm{BB}$ activation $(27,28)$ and a likely pro-tumorigenic role of $\mathrm{NF}-\kappa \mathrm{B}$ in skin carcinogenesis (29-31). In addition, NF- $\mathrm{kB}$ activation can lead to increased transcription of target genes such as cyclin $\mathrm{D}_{1}$ and anti-apoptotic $\mathrm{Bcl}_{2}$ family proteins (32). Surprisingly, in some mouse models, NF-kB inhibition induces cancer (33-38). Studies have shown that inhibiting $\mathrm{NF}-\kappa \mathrm{B}$ in initiated keratinocytes actually promotes squamous cell carcinogenesis by reducing 'terminal differentiation', an essential process for keratinocyte cell death (39). Thus, the up-regulation of NF-кB DNA-binding activity at $8 \mu \mathrm{g} / \mathrm{ml}$ of Salograviolide A in neoplastic cells could be, in fact, promoting epidermal differentiation that is preceding cell death.

Several recent studies have shown that sesquiterpene lactones generally possess an $\alpha$-methylene- $\beta$-lactone moiety essential for their apoptogenic and oxidizing activities, which in turn regulate the NF- $\mathrm{KB}$ signaling pathway $(8,21,40)$. We were able to show that ROS accumulation directly mediates Salograviolide A-induced growth inhibition in neoplastic epidermal cells.

Many studies have also reported that sesquiterpene lactones can induce apoptosis by enhancing the pro-apoptotic 
regulators, but without being able to alter the levels of antiapoptotic proteins $\mathrm{Bcl}_{2}$ and $\mathrm{Bcl}-\mathrm{x}_{\mathrm{L}}(41,42)$. In fact, our results show that Salograviolide A does not modulate the protein levels of $\mathrm{Bcl}_{2}$ or $\mathrm{Bcl}-\mathrm{x}_{\mathrm{L}}$ in neoplastic cells but increases the $\mathrm{Bax} / \mathrm{Bcl}_{2}$ ratio relative to the control by up-regulating the pro-apoptotic Bax protein levels. On the other hand, Centaurea ainetensis crude extract not only increases Bax protein levels in neoplastic keratinocytes but also concomitantly decreases $\mathrm{Bcl}_{2}$ protein levels. It is hence very likely that, in the crude extract, compounds other than Salograviolide $\mathrm{A}$ are acting in concert with this pure molecule in order to decrease $\mathrm{Bcl}_{2}$ levels in neoplastic keratinocytes.

Our results are the first to describe and characterize the antitumorigenic properties of Centaurea ainetensis crude extracts and of its purified component, Salograviolide A, in neoplastic epidermal cells. Several studies have suggested that the genus Centaurea comprises many secondary metabolites exhibiting several therapeutic values (7). However, only two reports addressed the biological activities of Salograviolide A, highlighting its antifungal (43) and anticolon cancer effects (44). In this study, we showed that, in a murine in vitro model, the papilloma and carcinoma cell lines are more sensitive to treatment with Centaurea ainetensis crude extract or Salograviolide A than the normal keratinocytes or spindle cells. Moreover, the fact that neither the crude extract nor the purified molecule, at the tested concentrations, are cytotoxic to primary keratinocytes necessitates in-depth analysis of the antitumor properties of Centaurea ainetensis and Salograviolide A on human squamous cell carcinogenesis.

\section{Acknowledgments}

This work was supported by grants from UNISANTIS and the research was conducted under the direction of the Initiative for Biodiversity Studies in Arid Regions (IBSAR) at the American University of Beirut, Lebanon.

\section{References}

1. Fauci AS, Braunwald E, Esselbach KJ, et al: Harrison's Principles of Internal Medicine. 14th edition. McGraw-Hill, New York, pp1300-1309, 1998.

2. Federman DG, Kravetz JD and Kirsner RS: Skin cancer screening by dermatologists: prevalence and barriers. J Am Acad Dermatol 46: 710-714, 2002.

3. Koyama J, Morita I, Tagahara K, et al: Chemopreventive effects of emodin and cassiamin $\mathrm{B}$ in mouse skin carcinogenesis. Cancer Lett 182: 135-139, 2002.

4. Williamson EM: Synergy and other interactions in phytomedicines. Phytomed 5: 401-409, 2001.

5. Mabberlay DJ: The Plant-Book. A portable dictionary of the vascular plants. 2nd edition. Cambridge University Press, Cambridge, p138, 1997.

6. Gurib-Fakim A: Medicinal plants: traditions of yesterday and drugs of tomorrow. Mol Aspects Med 27: 1-93, 2006.

7. Koukoulitsa E, Skalta H, Karioti A, Demetzos C and Dimas K: Bioactive sesquiterpene lactones from Centaurea species and their cytotoxic/cytostatic activity against human cell lines in vitro. Planta Med 68: 649-652, 2002.

8. Zhang S, Won YK, Ong CN and Shen HM: Anti-cancer potential of sesquiterpene lactones: bioactivity and molecular mechanisms. Curr Med Chem-Anti-Cancer Agents 5: 239-249, 2005.

9. Viguera Lobo JMY and Casabuena PA: Hypoglycemic action in the genus Centaurea II attempt at the separation of the active principle. Farmacognosia 13: 223-234, 1953.
10. Lee KH, Ibuka T, Wu RY and Geissman TA: Structureantimicrobial activity relationship among the sesquiterpene lactones and related compounds. Phytochem 16: 1177-1181, 1977.

11. Giordano OS, Pestchanker MJ, Guerreiro E, et al: Structureactivity relationship in the gastric cytoprotective effect of several sesquiterpene lactones. J Med Chem 35: 2452-2458, 1992.

12. Kabbout M, Hatoum A, Abou-Lteif G, Chakroun I, Homaidan FR and Darwiche N: Stage-specific effect of N-(4-hydroxyphenyl) retinamide on cell growth in squamous cell carcinogenesis. Mol Carcinog 40: 12-23, 2004.

13. Hennings H, Michael D, Cheng C, Steinert P, Holbrook K and Yuspa SH: Calcium regulation of growth and differentiation of mouse epidermal cells in culture. Cell 19: 245-254, 1980.

14. Yuspa SH, Koehler B, Kulesz-Martin M and Hennings $H$ : Clonal growth of mouse epidermal cells in medium with reduced calcium concentration. J Invest Dermatol 76: 144-146, 1981.

15. Srickland JE, Greenhalgh DA, Koceva-Chyla A, et al: Development of murine epidermal cell lines which contain an activated ras ${ }^{\mathrm{Ha}}$ oncogene and form papillomas in skin grafts on athymic nude mouse hosts. Cancer Res 48: 165-169, 1988.

16. Greenhalgh DA, Welty DJ, Player A and Yuspa SH: Two oncogenes, v-fos and v-ras, cooperate to convert normal keratinocytes to squamous cell carcinoma. Proc Natl Acad Sci 87: 643-647, 1990.

17. Yuspa SH, Kilkenny AE, Steinert PM and Roop DR: Expression of murine differentiation markers is tightly regulated by restricted extracellular calcium concentrations in vitro. $\mathrm{J}$ Cell Biol 109: 1207-1217, 1989.

18. Hatoum A, El-Sabban ME, Khoury J, Yuspa SH and Darwiche N: Overexpression of retinoic acid receptors alpha and gamma into neoplastic epidermal cells causes retinoic acid-induced growth arrest and apoptosis. Carcinogenesis 22: 1955-1963, 2001 .

19. Zou H, Henzel WJ, Liu X, Lutschg A and Wang X: Apaf-1, a human protein homologous to $C$. elegans CED-4, participates in cytochrome c-dependent activation of caspase-3. Cell 90: 405-413, 1997.

20. Young-Joon S: Cancer chemoprevention with dietary phytochemicals. Nat Rev Cancer 3: 768-780, 2003.

21. Valko M, Rhodes CJ, Moncol J, Izakovic M and Mazur M: Free radicals, metals and antioxidants in oxidative stress-induced cancer. Chem Biol Interact 160: 1-40, 2006.

22. Yuspa SH: The pathogenesis of squamous cell cancer: lessons learned from studies of skin carcinogenesis-thirty-third clowes memorila award lecture. Cancer Res 54: 1178-1189, 1994.

23. Robles AI, Rodriguez-Puebla ML, Glick AB and Trempus C: Reduced skin tumor development in cyclin D1-deficient mice highlights the oncogenic ras pathway. Genes Dev 12: 2469-2474, 1998.

24. Hochhauser D: Modulation of chemosensitivity through altered expression of cell cycle regulatory genes in cancer. Anticancer Drugs 8: 903-910, 1997.

25. Di Cunto F, Topley G, Calautti E and Hsiao J: Inhibitory function of $\mathrm{p} 21^{\mathrm{Cip} 1 / \mathrm{Waf} 1}$ in differentiation of primary mouse keratinocytes independent cell cycle control. Science 280: 1069-1072, 1998.

26. Aggarwal B and Shishodia S: Molecular targets of dietary agents for prevention and therapy of cancer. Biochem Pharmacol 71: 1397-1421, 2006.

27. Loercher A, Lee TL, Ricker JL, et al: Nuclear factor-kappaB is an important modulator of the altered gene expression profile and malignant phenotype in squamous cell carcinoma. Cancer Res 64: 6511-6523, 2004.

28 Budunova IV, Perez P, Vaden VR, Spiegelman VS, Slaga TJ and Jorcano JL: Increased expression of p50-NF-kappaB and constitutive activation of NF-kappaB transcription factors during mouse skin carcinogenesis. Oncogene 18: 7423-7431, 1999.

29. Bhatia N, Herter JR, Slaga TJ, Fuchs SY and Spiegelman VS: Mouse homologue of HOS (mHOS) is overexpressed in skin tumors and implicated in constitutive activation of NF-kappaB. Oncogene 21: 1501-1509, 2002.

30. Bell S, Degitz K, Quirking M, Jilg N, Page S and Brand K: Involvement of NF-kappaB signalling in skin physiology and disease. Cell Signal 15: 1-7, 2003.

31. Martin-Oliva D, O'Valle F, Munoz-Gamez JA, et al: Crosstalk between PARP-1 and NF-kappaB modulates the promotion of skin neoplasia. Oncogene 23: 5275-5283, 2004. 
32. Karin M and Lin A: NF-kappaB at the crossroads of life and death. Nat Immunol 3: 221-227, 2002.

33. Dajee M, Lazarov M, Zhang JY, et al: NF-kappaB blockade and oncogenic Ras trigger invasive human epidermal neoplasia. Nature 421: 639-643, 2003.

34. Maeda S, Kamata H, Luo JL, Leffert H and Karin M: IKKbeta couples hepatocyte death to cytokine-driven compensatory proliferation that promotes chemical hepatocarcinogenesis. Cell 121: 977-990, 2005.

35. Pasparakis M, Courtois G, Hafner M, et al: TNF-mediated inflammatory skin disease in mice with epidermis-specific deletion of IKK2. Nature 417: 861-866, 2002.

36. Van Hogerlinden M, Rozell BL, Ahrlund-Richter L and Toftgard R: Squamous cell carcinomas and increased apoptosis in skin with inhibited Rel/nuclear factor-kappaB signaling. Cancer Res 59: 3299-3303, 1999.

37. Van Hogerlinden M, Rozell BL, Toftgard R and Sundberg JP: Characterization of the progressive skin disease and inflammatory cell infiltrate in mice with inhibited NF-kappaB signaling. J Invest Dermatol 123: 101-108, 2004.

38. Zhang S, Ong CN and Shen HM: Critical roles of intracellular thiols and calcium in parthenolide-induced apoptosis in human colorectal cancer cells. Cancer Lett 208: 143-153, 2004.
39. Seitz CS, Lin Q, Deng H and Khavari PA: Alterations in NFkappaB function in transgenic epithelial tissue demonstrate a growth inhibitory role for NF-kappaB. Proc Natl Acad Sci USA 95: 2307-2312, 1998.

40. Kucharczak J, Simmons MJ, Fan Y and Ge'linas C: To be, or

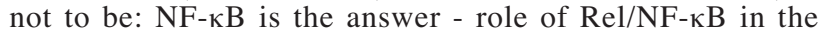
regulation of apoptosis. Oncogene 22: 8961-8982, 2003.

41. Choi JH, Ha J, Park JH, et al: Costunolide triggers apoptosis in human leukemia U937 cells by depleting intracellular thiols. Jpn J Cancer Res 93: 1327-1333, 2002.

42. Wen J, You KR, Lee SY, Song CH and Kim DG: Oxidative stress-mediated apoptosis. The anticancer effect of the sesquiterpene lactone parthenolide. J Biol Chem 277: 38954-38964, 2002.

43. Vajs V, Todorovic N, Ristic M, et al: Guaianolides from centaurea nicoli: antifungal activity. Phytochem 52: 383-386, 1999.

44. El-Najjar N, Dakdouki S, Darwiche N, El-Sabban M, Saliba NA and Gali-Muhtasib H: Anti-colon effects of Salograviolide A isolated from Centaurea ainetensis. Oncol Rep 19: 897-904, 2008 . 